\title{
Formule de lapte: Actualități şi recomandări
}

\author{
Laura Florescu', Oana-Raluca Temneanu', Dana-Teodora Anton Păduraru², \\ Dana Elena Mîndru' ${ }^{1}$ \\ ${ }^{1}$ Disciplina Puericultură, Departamentul Medicina Mamei şi Copilului, Universitatea de Medicină şi \\ Farmacie „Gr. T. Popa“, Iaşi, România \\ 2Disciplina Pediatrie, Departamentul Medicina Mamei şi Copilului, Universitatea de Medicină şi \\ Farmacie „Gr. T. Popa", Iaşi, România
}

\begin{abstract}
REZUMAT
Un copil sănătos traversează un proces de creştere şi dezvoltare armonioasă, mediul din care face parte şi calitatea alimentaţiei reprezentând premisele determinante ale sănătăţi îndeosebi în primii 2 ani de viaţă.

Atunci când alimentarea cu lapte matern nu este posibilă din cauza lipsei instalării secreţiei lactate ori a unei cantităţi insuficiente de lapte uman, sursele alternative de alimentaţie constau în administrarea de formule de lapte, iar în condiţii socio-economice precare, lapte de vacă. Deoarece fiecare are nevoi individuale, există o varietate de formule de lapte, astfel încât copilul să aibă o alimentaţie calitativă şi cantitativă corespunzătoare, optimă pentru o dezvoltare armonioasă. Nu numai că există mai multe categorii de formule, pe bază de proteine din lapte, de soia, proteine hidrolizate şi aminoacizi, dar există diferenţe între produsele din fiecare categorie.
\end{abstract}

Cuvinte cheie: formule de lapte, formulă de început, formulă de continuare

În prezent, organismele internaționale avizate (OMS - Organizația Mondială a Sănătății, UNICEF - Fondul Internațional pentru Urgențe ale Copiilor al Națiunilor Unite), dar şi naționale (IOMC - Institutul pentru Ocrotirea Mamei şi Copilului), promovează alimentaţia naturală şi notează că aceasta reprezintă o problemă de sănătate publică, recomandarea fiind în acord cu dinamica descoperirilor ştiințifice din ultimele decade, care susțin importanța administrării laptelui matern pentru sănătatea copilului şi a viitorului adult. De asemenea, marile religii ale lumii proclamă obligația mamei de a alăpta: Creştinismul, prin Papa Ioan Paul al IIlea, iudaismul, prin Vechiul Testament, Islamul, prin Coran.

Printre inițiativele proalăptare la nivel mondial, se numără Săptămâna Internaţională a Alăptării (1), existenţa consultanţilor în alăptare în diferite oraşe. Datele statistice internaționale reprezintă un semnal de alarmă, rata aderenței la alaptare fiind în scădere (2); de aceea, forurile decizionale mondiale, dar şi cele naționale, au adoptat un cadru legislativ favorabil alimentației naturale.
Alimentația optimă a copiilor presupune o dimensiune cantitativă şi una calitativă. Dezechilibre înregistrate în direcție ascendentă sau, dimpotrivă, descendentă, pot duce la malnutriție, supraalimentație, dar şi diverse carențe alimentare, din cauza unui deficit persistent al unui anume nutrient. Se iau în considerare anumite particularităţi nutritive ale copilului, care presupun, înainte de toate, nevoi calorice foarte crescute la sugar (măsurate pe kilogram corp/zi); în primele luni de viață. Acestea vor înregistra o scădere progresivă până în perioada pubertară, când vor creşte din nou, considerabil. O importanță majoră se acordă fracției proteice, care trebuie să fie constantă, pentru a asigura un ritm fiziologic al creşterii, dar şi corespunzătoare din punct de vedere calitativ, sugarul având nevoie de mai mulţi aminoacizi esenţiali şi semiesenţiali. De asemenea, sugarul are nevoi crescute de apă, care sunt susceptibile la fluctuații rapide, în cazul unor pierderi crescute.

Recomandările unanim acceptate în prezent sunt de alimentație naturală exclusivă până la 6 luni, inițierea alimentației complementare după această 
vârstă şi continuarea alăptării până la vârsta de 2 ani (3).

În situația în care copilul nu poate beneficia de lapte uman, parțial sau în totalitate, se va recurge la administrarea de preparate de lapte praf obținute prin prelucrarea laptelui de vacă, capră sau din soia, cu o compoziție cât mai apropiată de laptele uman, care au primit denumirea de formule de lapte. În timp, industria formulelor de lapte a evoluat, astfel încât, indiferent de patologia asociată sau particularitățile individuale, cu siguranță se va găsi formula potrivită care să asigure o creştere şi dezvoltare corespunzătoare.

„Formulele de inceput" sunt produsele alimentare destinate să fie utilizate de sugari în primele luni de viață şi care îndeplinesc prin ele însele cerinţele nutriţionale de creştere şi dezvoltare armonioasă ale acestora până la introducerea unei alimentații complementare corespunzătoare.

„Formulele de continuare" constituie un aliment destinat să fie utilizat de sugari atunci când se introduce o alimentație complementară corespunzătoare şi care constituie principalul element lichid din alimentația diversificată progresiv a acestor sugari.

Formula de început şi formula de continuare sunt produse complexe, elaborate special pentru un grup vulnerabil de consumatori. Pentru a putea fi utilizate în siguranță, trebuie să fie stabilite cerințe detaliate privind compoziția, respectiv valoarea energetică, conținutul de macronutrienți şi micronutrienți. Aceste cerințe trebuie să se bazeze pe cele mai recente avize ştiinţifice ale Autorităţii Europene pentru Siguranța Alimentară (EFSA - European Food Safety Authority), în avizul său cu privire la compoziția esențială a formulelor de început şi a formulelor de continuare (4).

Clasificarea formulelor de lapte se face după grupa de vârstă la care se recomandă sau în funcție de compoziție $(5,6)$.

Clasificarea formulelor în funcție de vârstă:

- formule pentru copii cu greutate mică la naştere - LWBF (low birth weight formula);

- formule pentru sugari (0-6/12 luni) - IF (infant formula);

- formule de continuare (6-12/36 luni) - FOF (follow-on formula);

- lapte de creştere (peste 10/12 luni) - GUM (growing-up milk);

- formule speciale, pentru sugari cu anumite nevoi fiziologice şi/sau metabolice - FSMP (formulae for special medical purpose).
Clasificarea formulelor în funcție de compoziție:

- cu proteine din lapte de vacă;

- cu proteine din zer;

- cu proteine din soia;

- cu aminoacizi ca unică sursă de proteine (formule elementale);

- cuagenți deîngroşare (formule antiregurgitații $-\mathrm{AR}$ );

- delactozate (7).

Noua legislație din Uniunea Europeană (UE) privind formulele de lapte a fost publicată în jurnalul oficial al UE în februarie 2016:

- REGULAMENTUL DELEGAT (UE) 2016/ 127 AL COMISIEI din 25 septembrie 2015 de completare a Regulamentului (UE) nr. 609/2013 al Parlamentului European şi al Consiliului în ceea ce priveşte cerinţele specifice privind compoziția şi informarea pentru formulele de inceput şi formulele de continuare şi în ceea ce priveşte cerințele privind informațiile privitoare la alimentaţia sugarilor şi a copiilor de vârstă mică

- REGULAMENTUL DELEGAT (UE) 2016/ 128 AL COMISIEI din 25 septembrie 2015 de completare a Regulamentului (UE) nr. 609/2013 al Parlamentului European şi al Consiliului în ceea ce priveşte cerințele specifice privind compoziția şi informarea aplicabile alimentelor destinate unor scopuri medicale speciale (8).

În aceste documente, sunt precizate clar nevoile energetice (Tabelul 1), cantitatea de macro şi micronutrienţi necesară şi admisă pentru formulele de inceput şi formulele de continuare.

TABELUL 1. Nevoile energetice

\begin{tabular}{|c|c|}
\hline Minimum & Maximum \\
\hline $250 \mathrm{~kJ} / 100 \mathrm{ml}$ & $293 \mathrm{~kJ} / 100 \mathrm{ml}$ \\
\hline$(60 \mathrm{kcal} / 100 \mathrm{ml})$ & $(70 \mathrm{kcal} / 100 \mathrm{ml})$ \\
\hline
\end{tabular}

\section{Proteinele}

Dintre macro şi micronutrienții esenţiali cunoscuți, proteinele sunt cele mai importante pentru dezvoltarea şi sănătatea organismului. Proteinele sunt substanțe organice macromoleculare formate din lanţuri simple sau complexe de aminoacizi; ele sunt prezente în celulele tuturor organismelor vii în proporție de peste $50 \%$ din greutatea uscată. Toate proteinele conţin aceiaşi 20 de aminoacizi, dar în diferite combinații (inclusiv cu alte componente glucide, lipide, elemente anorganice etc.) şi aranjamente chimice. Proteinele influențează toate aspectele creşterii şi dezvoltării. Laptele matern conține cantitatea şi calitatea ideală de proteine. Compoziția proteică a laptelui matern evoluează în timp 
pentru a se suprapune cu nevoile în evoluție ale sugarului (9).

Spre deosebire de laptele matern, unele formule standard pentru sugari supraîncarcă cu proteine sugarii de la o vârstă critică. Dovezi stiințifice relevă importanța aportului de proteine pentru sănătatea metabolică pe termen lung; potrivit „Early Protein Hypothesis", aportul excesiv de proteine în primul an de viață ,programează“ o tendință spre o creştere rapidă în greutate şi formarea de celule adipoase (activitate adipogenică) (10).

Utilizarea hidrolizatelor proteice ca sursă de proteine în formulele de început şi în formulele de continuare a fost permisă în temeiul Directivei 2006/141/CE timp de mulți ani. Conform noii legislații UE, cantitatea de proteine în Formulele de inceput pe bază de proteine din lapte de vacă $s$-a modificat de la 1,8-3 g/100 kcal la 1,8-2,5 g/100 kcal, iar în Formule de inceput pe bază de hidrolizate proteice, dacă limitele vechi erau $<2,8 \mathrm{~g} / 100$ kcal, în prezent, cerințele sunt 1,86-2,8 g/100 kcal. Formulele pe bază de hidrolizate proteice conțin ca sursă proteică proteine din zer dulce demineralizat, derivate din lapte de vacă după precipitarea enzimatică a cazeinei cu ajutorul chimozinei, constând în:

a. $63 \%$ izolat de proteine din zer fără cazeinoglicomacropeptidem cu un conținut minim de proteine de 95\% din substanța uscată, o denaturare a proteinelor mai mică de $70 \%$ şi un conținut maxim de cenuşă de 3\%; precum şi

b. $37 \%$ concentrat de proteine din zer dulce cu un conținut minim de proteine de $87 \%$ din substanța uscată, o denaturare a proteinelor mai mică de $70 \%$ şi un conținut maxim de cenuşă de $3,5 \%$.

\section{Lipidele}

Adăugarea obligatorie de acid docosahexaenoic (DHA) la formulele de început şi formulele de continuare este o nouă cerință introdusă de prezentul regulament, recomandată recent de Autoritate în avizul său cu privire la compoziția esențială a formulelor de început şi a formulelor de continuare (DHA: 20-50 mg/100 kcal). De asemenea, s-au modificat limitele pentru acidul linoleic şi alfa linolenic şi s-au eliminat limitele pentru acidul miristic şi lauric. Se interzice utilizarea următoarelor substanțe: ulei din semințe de susan, ulei din semințe de bumbac.

\section{Carbohidraţii}

Se pot utiliza numai următorii carbohidrați: lactoza, maltoza, zaharoza, glucoza, siropul de gluco- ză sau siropul de glucoză deshidratat, maltodextrinele, amidonul pretratat termic (care nu conține gluten în mod natural), amidonul gelatinizat (care nu conține gluten în mod natural).

Se pot adăuga numai în formulele pe bază de hidrolizate proteice:

- Zaharoza maximum $20 \%$ din carbohidrați;

- Glucoza $<2$ g/100 kcal;

- Siropul de glucoză sau siropul de glucoză deshidratat $<0,84 \mathrm{~g} / 100 \mathrm{kcal}$.

\section{Lactoza}

Mențiunea „numai lactoză“ poate fi utilizată pentru formulele de început şi formulele de continuare, cu condiția ca lactoza să fie singurul glucid prezent în produs.

Mențiunea „fără lactoză“ poate fi utilizată în formulele de început şi în formulele de continuare, în situația în care conținutul de lactoză din produs nu depăşeşte $2,5 \mathrm{mg} / 100 \mathrm{~kJ}(10 \mathrm{mg} / 100 \mathrm{kcal})$.

Fructo-oligozaharidele şi galacto-oligozaharidele pot fi adăugate în formulele de început. În acest caz, conținutul lor nu trebuie să depăşească: $0,8 \mathrm{~g} / 100 \mathrm{ml}$, într-o combinație de $90 \%$ oligogalactozil-lactoză şi de 10\% oligofructozil-zaharoză cu greutate moleculară mare. Alte combinații şi conţinut maxim de fructo-oligozaharide şi galacto-oligozaharide pot fi utilizate, cu condiția ca adecvarea lor pentru sugari să fie demonstrată.

Se stabilesc restricții mai severe în cazul unui număr mic de pesticide sau de metaboliți de pesticide, pentru care chiar şi o limită maximă de reziduuri (LMR) de $0,01 \mathrm{mg} / \mathrm{kg}$ ar putea conduce, în cazul cel mai grav, de consum în exces, la o expunere care depăşeşte doza zilnică acceptabilă (DZA) pentru sugarii şi copiii de vârstă mică (11).

O categorie aparte o constituie copiii cu alergii alimentare, cu sau fără istoric familial de atopie. Alimentația din primele luni de viață poate influenta probabilitatea de a dezvolta o alergie mai târziu. În urma expunerii la antigene alimentare, la nivelul barierei mucoasei intestinale are loc o procesare imunologică, care poate determina atât fenomene de protecție şi toleranță alimentară, cât şi fenomene de tip alergic. În prezent, când alăptarea exclusivă nu este posibilă, recomandarea este de a utiliza o formulă hipoalergenică (HA) cu efecte dovedite ştiinţific la sugarii cu istoric familial de alergii, iar recomandările experților francezi subliniază că o formulă HA ar trebui să fie utilizată şi pentru copiii al căror istoric familial este necunoscut.

Dintre toate alergiile alimentare ale copiilor, alergia la proteinele din laptele de vacă (APLV) 
este cel mai des întâlnită şi afectează aproximativ $3 \%$ dintre sugari (12). APLV este definită ca o reacție adversă reproductibilă la una sau mai multe proteine din lapte (de obicei cazeine sau zer precum $\beta$-latoglobulina) şi poate fi Ig E sau non Ig E mediată. APLV poate apărea şi la sugarul alăptat exclusiv; fenomenul poate avea loc prin transferul de proteine de la mamă la sugar prin laptele matern.

Se cunoaşte faptul că alergia la un lapte de un mamifer poate implica alergie şi la laptele de la alt mamifer, respectiv ,alergii încrucişate“ (13).

Există şi formule pe bază de lapte de capră. Proteinele din laptele de capră sunt digerate mai bine decât proteinele din laptele de vacă. Conform studiilor, acesta ar fi mai uşor digerabil, încărcătura alergenică fiind semnificativ mai mică comparativ cu laptele de vacă. Dar nu trebuie să uităm că indivizii care sunt foarte sensibili la proteinele din laptele de vacă trebuie sfătuiți să consulte medicul înainte de a consuma lapte de capră (14).

Formulele pe bază de soia sunt disponibile de aproape 100 de ani. De la prima utilizare a formulei de soia ca înlocuitor de lapte pentru un copil care nu poate tolera o formulă bazată pe proteine din lapte de vacă, compoziția s-a îmbunătățit continuu. Formulele cu proteine din soia se recomandă în alergia/intoleranța la proteinele laptelui de vacă, cu mențiunea că există cazuri de alergie încrucişată, situaţie în care se vor folosi formulele hipoalergenice care au în compoziție hidrolizate de proteine/ aminoacizi $(15,16)$.

Nou-născuții cu greutate mică la naştere (LBW), indiferent dacă se încadrează sau nu în categoria prematurilor, au caracteristici şi nevoi speciale (17). Formulele recomandate copiilor LBW prezintă un conţinut mai ridicat de proteine - predomină cele din zer; cantități mai mari de glucide; lipide (uleiuri vegetale şi trigliceride cu lanț mediu); un raport proteine/calorii mai mare, comparativ cu formulele standard (18). Fortifianții de lapte uman, sintetizați din laptele de vacă, sunt utilizaţi în mod obişnuit pentru alimentația nou-născuților cu greutatea la naştere $<1.500 \mathrm{~g}$, pe perioada spitalizării lor, lichidul de diluție fiind laptele matern. În cazul copiilor născuți prematur, în special cei VLBW, laptele matern are un aport insuficient de proteine şi calorii. Utilizarea laptelui uman fortifiat determină o recuperare staturo-ponderală adecvată în rândul prematurilor, satisfăcând nevoile nutriționale specifice ale acestei categorii de copii (19).

\section{CONCLUZII}

Primele 1.000 de zile, încă de la începutul sarcinii, sunt esențiale pentru dezvoltarea sănătoasă a viitorului adult. Laptele matern reprezintă alimentul ideal pentru sugari; OMS recomandă alăptarea exclusivă până la 6 luni, urmată de continuarea alăptării cât mai mult timp posibil, alături de diversificarea alimentației. În situația în care copilul nu poate beneficia de lapte uman, parțial sau în totalitate, se va recurge la administrarea de preparate de lapte praf. Înțelegerea necesităţii administrării unei alimentații corespunzătoare calitativ şi cantitativ a condus la dezvoltarea unor formule de lapte, care asigură necesarul de macro şi micronutrienţi, atât pentru sugarii sănătoşi, cât şi pentru cei care prezintă diferite patologii (de exemplu, reflux gastroesofagian, intoleranța la lactoza, alergie la proteinele laptelui de vacă, sindroame de malabsorbție, prematuri). Formulele dietetice sunt „sigure“ din punct de vedere al aportului nutrițional, în sensul că sunt complete din punct de vedere nutritiv şi nu induc carențe. Administrarea unei formule de lapte se va face în urma consilierii nutriționale realizate de către un medic, care va identifica particularitățile de creştere şi dezvoltare pentru fiecare copil în parte.

Conflict of interest: none declared Financial support: none declared 